\title{
Introduction: The neighbourhoods issue is the regionalisation issue
}

The European ESPON research programme ${ }^{1}$ tries to bridge the gap between researchers and policy makers on territorial issues. This book provides, regarding the Mediterranean neighbourhood, the main results of the ITAN project ('Integrated Territorial Analysis of the Neighbourhoods', 2011-2015). Within ESPON, ITAN was the first project dedicated to the neighbour territories as such. This is of utmost importance, given the rising role of the neighbourhoods not only for Europe but in the other world regions, namely in the two leading ones: North America (including Mexico since the North American free trade agreement) and East Asia (i.e. Japan and its developing and emerging neighbours including China). In the last four decades, everybody has been well aware of the globalisation of migration, cultural and economic flows. However, the other major feature of the world space's new organisation has been largely underestimated: regionalisation, that is to say, the growing interaction between neighbour countries. The more competition, complexity and uncertainty rise along with globalisation, the more regionalisation appears to be a steady base for a strong competitive position vis-à-vis the rest of the world. Especially when they are emerging countries, neighbours provide further markets, an available and ever more skilled labour force and partnership for a safer political and ecological environment - water or air pollution does not stop at the EU or at the US borders and neither do migrants. In other words, proximity still matters.

Numerous events demonstrate the challenges of globalised regulation: the recurring failures of the World Trade Organization's Doha cycle have proved the difficulty of accommodating the imperatives of open trade and reducing poverty in developing countries. The global financial crisis showcased the dire need for regulation in the financial sector and widened the chasm between North and South insofar as the North changed the rules of the game when its vital interests were at stake (massive subsidies after professing to the South public disengagement and free competition). The hazards of climate change call for international action on which global conferences hardly reach consensus. As reflected in the positions adopted by the Food and Agriculture Organization (Matthews 2003) and United 
Nations Conference on Trade and Development favouring regional agreements (Mashayekhi and Ito 2005), the regionalisation of efforts to regulate international relations is increasingly viewed as a complement to global regulation.

Economists and political scientists have long debated the benefits and disadvantages of regionalism (Baldwin 1997; De Lombaerde and Soderbaum 2014). For proponents of multilateral free trade, regionalism has more to do with partisan political concerns than achieving economic optimum and would only generate additional bureaucratic costs, such as that of defining and enforcing laws with respect to 'rules of origin' in order to commercially protect products originating in the region. Regional free trade agreements would not resemble legible agreements so much as they would be a 'spaghetti bowl', to use the term coined by Jagdish Bhagwati (1995) in one widely read article. Recent facts provide some support to this view: since the beginning of the 1990s, the number of regional free-trade agreements in existence has grown from 27 to 420 in 2016! Worse yet, regionalism would result in the establishment of blocs leading eventually to high-level trade and political confrontations. In the event of fragmentation of the international currency system into a dollar region (Americas), a yen-yuan region and a euro region, relations between these monetary blocs would pose momentous trade challenges. Lastly, regionalism would dramatically isolate the developing countries which would be left outside of the major alliances.

For other analysts, regionalism would, to the contrary, support regulation of activity sectors governed by proximity, such as transport, tourism, pollution control and gas and electricity distribution (Taillard 2004). More specifically, it would facilitate regulation processes between countries of the North and countries of the South at which global multilateralism fares poorly. Regions would not be fortresses standing in the way of global free trade; open regionalism may be, as acknowledged in World Trade Organization regulations, a phase in developing countries' entry into open trade that the Doha cycle was never successful in promoting, and that basic bilateral agreements with countries of the North transform into unbalanced power relationships. Relationships of trust are doubtless easier to foster amongst a few countries than amongst 200; this may aid developing countries in playing the game of open trade insofar as they perceive regional pacts as more controllable and, potentially, more reversible than generalised agreements with countries around the world.

What is the situation between Europe and its Mediterranean developing neighbours? During the last three decades, Europe has lost some of its economic and political influence on its neighbourhoods. This means that Europe has managed to become a region by letting European countries 
become members of the European Union, but failed in gathering developing neighbour countries so as to constitute a major 'North-South region'. The crucial issue for Europe is to know whether its relevant 'region' should be the EU, or the wider area gathering the EU and its neighbours, especially in the Mediterranean (Grasland and Didelon 2007).

In 1995, the Barcelona Process was launched to create a Mediterranean region of peace, security and shared prosperity. Since then, the partnership has been enhanced and reformulated by the European Neighbourhood Policy in 2007 (EC 2003) and the Union for the Mediterranean in 2008. Nevertheless, the Euro-Mediterranean region has rather experienced de-integration in terms of economic, cultural and political exchanges (Galal and Reiffers 2010). This is particularly the case of the Near East where the influence of the Gulf countries is growing, with declining common social, cultural and political references with Europe. Since the rise of the Arab Spring in 2011, the on-going turmoil in the Arab partner countries demonstrates that these countries have entered an economic and political transition, each country at its own speed and on its own path, but all of them painfully. It also confirms that the EU has been unable to shape its Mediterranean neighbourhood's destiny, whereas Japan, as soon as the Second World War ended, had a vision of the strategic complementary with its developing neighbours which has given birth to Dragons and Tigers. Mediterranean neighbours see Europe as an envied land on the one hand but as a political dwarf on the other (Grasland et al. 2012). For their part, Europeans see their Mediterranean neighbourhood as a troublesome area, with low awareness that its political and economic transition will last decades and that they should help this transition move to a win-win situation.

As a whole, the Euro-Mediterranean region lacks a shared vision which could mobilise North and South public, private and collective stakeholders, on local, national and international scales. This is the reason why the European External Action Service of the EU launched in March 2015 a consultation dedicated to deeply reformulate the European Neighbourhood Policy (HRUFASP and European Commission 2015a). This text - the best ever written by the EU on the neighbourhoods recognises the failure: we expected a 'circle of friends', we rather have a circle of fire, they realistically say. However, no real improvement came out of this consultation: the EU still sees its Mediterranean partnership through security concerns as a way to ensure peace, and free trade as the dominant driver to prosperity. The recent Syrian refugee crisis proves once more the European decision-makers' inability to address the neighbourhood issue in a more ambitious view, and confirms the rising distrust of Mediterranean neighbours vis-à-vis the Union. 
Table I.1 The territorial approach of the neighbour countries: many fields of interest, for many stakeholders

\begin{tabular}{|c|c|}
\hline Fields & Examples \\
\hline $\begin{array}{l}\text { International 'on-the-ground' } \\
\text { cooperation when diplomacy is } \\
\text { stalling }\end{array}$ & Decentralised cooperation \\
\hline Cross-border cooperation & $\begin{array}{l}\text { Opportunities for the peripheral European } \\
\text { local authorities }\end{array}$ \\
\hline $\begin{array}{l}\text { Promotion of territorial planning, } \\
\text { decentralisation and local } \\
\text { democracy in European } \\
\text { neighbour countries (ENCs) }\end{array}$ & $\begin{array}{l}\text { See the strong demand for inclusive growth } \\
\text { in Mediterranean partner countries since } \\
\text { the Arab Spring }\end{array}$ \\
\hline $\begin{array}{l}\text { Common policies and projects } \\
\text { (EU + neighbour countries) }\end{array}$ & $\begin{array}{l}\text { Environment: sanitation, de-pollution } \\
\text { of the Mediterranean }\end{array}$ \\
\hline $\begin{array}{l}\text { Monitoring of European policies } \\
\text { in the neighbour areas }\end{array}$ & $\begin{array}{l}\text { Rural development: ENPARD project } \\
\text { in North Africa (ENPARD = rural } \\
\text { development in the Mediterranean } \\
\text { neighbourhood) }\end{array}$ \\
\hline $\begin{array}{l}\text { Extension of the European } \\
\text { networks to ENCs }\end{array}$ & $\begin{array}{l}\text { Transport: norms extension and enlarged } \\
\text { business opportunities }\end{array}$ \\
\hline $\begin{array}{l}\text { Identification of dynamic } \\
\text { territories in ENCs }\end{array}$ & $\begin{array}{l}\text { Opportunities for investors (infrastructures, } \\
\text { clusters) }\end{array}$ \\
\hline
\end{tabular}

This book suggests avenues for Europe to regain, by a territorial approach, a part of its lost influence (Table I.1). The territorial approach is a good way to foster partnership when diplomatic relations are stalling, and when Mediterranean neighbours increasingly deal with other global or emerging players such as the US, China, Brazil or the Gulf states.

The book is based on one idea: if the Euro-Mediterranean stakeholders want to share a vision of their common region, they first have to share common geographic data on transport, energy, agriculture, water, environment and social and economic issues. Conducted thanks to a deep cooperation between teams of an international European consortium and with scholars and experts of the Mediterranean neighbour countries, the ITAN project is the initial stage for such comprehensive database at local scale; it allows comparisons between South Mediterranean territories, as well as between them and European ones because the database is compliant with that of the EU.

The book shows pioneering maps on the Mediterranean neighbour territories. It also gathers country analysis from Morocco to Turkey, including the occupied Palestinian territory and Jordan - what we sometimes call 
'South Mediterranean countries', as distinguished from the 'North', that is to say Europe. We acknowledge that placing Turkey among the 'South Mediterranean countries' and not among the 'European' is questionable; consider it a simple classification, and not a substantial thinking of what would be Turkey's profound 'nature' or its political future. For the first time, the book provides maps at the scale of the wider Euro-Mediterranean region, that is to say EU + Mediterranean neighbours. Such a comprehensive territorial analysis at a local scale had never been done before. That is why the geography displayed here is said to be 'integrated', from the local (wilaya, province or district) scale to that of the wider region. Usual maps on the Mediterranean are scattered: some deal with agriculture, others with energy or transport; some deal with the Near East (Balanche 2012), others with the Maghreb; some deal with investment, others with environment, etc. We do not pretend to provide a comprehensive view of the Mediterranean - all the more so as we hardly analyse the geopolitical issue. However, this book is the first step towards such a comprehensive view, and a condition for an overall understanding of the Mediterranean stakes that could lead to a shared vision for a deeply integrated EuroMediterranean region.

The first part of the book presents the main territorial stakes of Europe's Mediterranean neighbourhood. It proposes avenues for policies that would be common to Europe and its southern neighbours. The driving idea here is that Europe needs these neighbours as much as these neighbours need Europe. In the second part we explain the importance of the local data issue for an integrated geography, in particular the problem of comparability and the need for harmonisation of data stemming from very numerous and heterogeneous countries and datasets. The lack of international cooperation in this field makes this harmonisation task an incredible challenge. This calls for a Euro-Mediterranean collaborative platform that could provide researchers and territorial actors with comparable data, regular country reports on territorial issues and an overall Neighbourhoods Territorial Agenda dedicated to the regional main projects. The third part focuses on country analyses. They follow the same pattern so as to permit further comparable analysis: the administrative division of the national space, the local competencies and their evolution; the national statistical system and local data available for territorial studies; the human occupation of space and the demographic dynamics; social disparities, economic and environmental issues analysed through a territorial approach. The fourth part of the book presents the Gibraltar case study. It shows that competition is rising between the two sides of the Strait, and that the southern side will more and more converge with the northern in the coming decades. However, it also shows the complementarity and 
the cooperation between North and South - a metaphor of the EuroMediterranean regional integration's challenges.

\section{NOTE}

1. European Observation Network, Territorial Development and Cohesion, https://www. espon.eu. 